\title{
Recent patent applications in protein purification
}

\begin{tabular}{|c|c|}
\hline Patent number & Description \\
\hline $\begin{array}{l}\text { WO } 2008101667 \text {, } \\
\text { US } 20080249014\end{array}$ & $\begin{array}{l}\text { A method of obtaining highly purified } \\
\text { hydrophobic protein comprising extracting } \\
\text { the retentate by microdiafiltration using a } \\
\text { buffer-solution containing a detergent and } \\
\text { subjecting the filtrate to hydroxyapatite } \\
\text { column chromatography. }\end{array}$ \\
\hline US 20080221026 & $\begin{array}{l}\text { A method of manufacturing a nematode- } \\
\text { extracted anticoagulant protein (NAP) drug } \\
\text { substance comprising fermenting, recover- } \\
\text { ing NAP from cells and cellular debris, and } \\
\text { purifying the NAP drug substance away } \\
\text { from contaminants. }\end{array}$ \\
\hline
\end{tabular}

US $20080221309 \quad$ A new biologically active recombinant

Pastorek J, Pastorekova S, Pastorek J, Pastorekova S, 3/11/1992 Priority Assignee Inventor application date Publication date

$8 / 28 / 2008$,

(Wallisellen, Switzerland),

$9 / 19 / 2008$

Baxter International

(Deerfield, IL, USA),

Mitterer A, Tauer C

Dendreon (Seattle)

Lidell J, Mendoza CB, 5/15/2003

$9 / 11 / 2008$

Moss D

antibody or biologically active recombin

prognostically, therapeutically, for imag-

ing, and/or for affinity purification of

proteins.

WO $2008104606 \quad$ Producing multimers of immunoglobulins in a cultured cell by co-expressing heavy chain, light chain and $\mathrm{J}$ chain and the endoplasmic reticulum Golgi intermediate compartment (ERGIC)-53 protein and purifying the cell culture supernatant.

US 20080203351, A magnetic nanocrystal, where the surCN 101241788 face of the nanocrystal is bonded with a biocompatible macromolecule and an alkyl-containing molecule simultaneously; useful, for example, in biological applications such as DNA/RNA, protein and cell separation and purification.

WO 2008097870 , US 20080206262

A method for increasing the effectiveness of antigen presentation comprising isolating and purifying a dendritic cell asialoglyco protein receptor (DC-ASGPR)specific antibody or its fragment.

WO 2008097829

\section{Producing an active mammalian}

$\mathrm{N}$-acetylglucosaminyltransferase I (GnT1) protein in bacteria comprising expressing the mammalian GnT1 protein in bacteria and solubilizing, refolding and purifying the soluble mammalian GnT1 protein.

WO 2008091740

CN 101195651

CN 101157059

EP 1876183 ,

Johnson KF, Schwartz MF, 2/2/2007

$8 / 14 / 2008$

$8 / 28 / 2008$ $8 / 13 / 2008$

The Chinese Academy of

Sciences (Beijing), Gao M,

Gao M, Hu F, Liu S, Lu X 1/15/2007

9/11/2008 Zavada J

$9 / 4 / 2008$

Baylor Research Institute Banchereau JF, Li D, Oh S, 2/2/2007

$8 / 14 / 2008$ $8 / 28 / 2008$

Neose Technologies Wu B A method for purifying antibodies compris- Genentech (So. San ing adjusting the acidity or salt concentra- Francisco, CA, USA), tion of a mixture containing an antibody, Fahrner RL, Franklin J, adding a negatively or positively charged McDonald P, Peram T, polyelectrolyte, and separating the protein- Sisodiya V, Victa C polyelectrolyte precipitate.

A method of protein concentration/purification comprising using the difference between the charge properties of protein and amino acid ions under the action of an electric field and through gel crossover to move the protein from one container to another.

A non-aperture amphoteric ion-exchange biological separating medium used for separating and purifying protein, enzyme and products.

New factor VIII ligand peptide compounds Technische Universitat useful for producing, labeling, detecting, Munchen (Munich) diagnosing, monitoring, identifying, isolat-

Guilin Medical College (Guangxi, China)

Chen S, Chou X, Li S, Lu M, Shi W

Fahrner RL, Franklin J,

$1 / 22 / 2007$ cDonald P, Peram T, Sisodiya V, Victa C

Ningxia University

(Yinchuan, China)

ing, purifying, stabilizing and/or enhancing the activity of factor VIII or VIII-like protein and treat hemophilia A.

Source: Thomson Scientific Search Service. The status of each application is slightly different from country to country. For further details, contact Thomson Scientific, 1800 Diagonal Road, Suite 250, Alexandria, Virginia 22314, USA. Tel: 1 (800) 337-9368 (http://www.thomson.com/scientific). 